\title{
Aeromonas spp. ISOLATED FROM OYSTERS (Crassostrea rhizophorea) FROM A NATURAL OYSTER BED, CEARÁ, BRAZIL
}

\author{
Norma S. EVANGELISTA-BARRETO(1), Regine H.S.F. VIEIRA(1), Fátima Cristiane T. CARVALHO(1), Regina C.O. TORRES(2), Ernani S. SANT'ANNA(2), \\ Dália P. RODRIGUES(3) \& Cristhiane M.F. REIS(3)
}

\begin{abstract}
SUMMARY
Between April and October 2002, thirty fortnightly collections of oysters (Crassostrea rhizophorea) from a natural oyster bed at the Cocó River estuary in the Sabiaguaba region (Fortaleza, Ceará, Brazil) were carried out, aiming to isolate Aeromonas spp. strains. Oyster samples were submitted to the direct plating (DP) and the presence/absence (P/A) methods. Aeromonas were identified in $15(50 \%)$ samples analyzed by the DP method and in $13(43 \%)$ analyzed by the P/A method. A. caviae, A. eucrenophila, A. media, A. sobria, A. trota, A. veronii bv. sobria, A. veronii bv. veronii and Aeromonas sp. were isolated. The predominant species was A. veronii (both biovars), which was identified in 13 (43\%) samples, followed by A. media in 11 (37\%) and A. caviae in seven (23\%). From the 59 strains identified, 28 (48\%) presented resistance to at least one of the eight antibiotics tested.
\end{abstract}

KEYWORDS: Aeromonas; Oysters; Antibiotics.

\section{INTRODUCTION}

Shellfish consumption has been showing a sustainable growth in recent years, mainly in developing countries. The consumption of marine products is worthy due to its nutritious value and low cholesterol levels. However, marine products may be a vehicle for most known pathogenic bacteria ${ }^{8}$.

Bivalve mollusks, due to their filtering characteristic, are used as bioindicators. Oysters' meat microbiota is directly related to the environment from which they come from, although in higher concentrations, due to their bioaccumulation mechanism.

The Aeromonas genus is primary autochthonous from the aquatic environment ${ }^{25}$. Its taxonomy has been constantly reevaluated based initially on its phenotype characteristics, including the metabolic and antigenic ones, this last being the one used solely as an epidemiological tool. The use of those methods capable of performing a genotype characterization indicated spatial genetic complexity among mesophilic species being characterized in phenospecies and genospecies, although its toxicity is not already well defined ${ }^{11}$.

Some species of Aeromonas are responsible for a significant number of intestinal and extra-intestinal infections in humans and also in animals (fishes) ${ }^{9,26}$. Even though Aeromonas are isolated from patients with diarrhea its etiological role in gastroenteritis is still not clear ${ }^{1}$. It is believed that the difficulty in assigning an unequivocal role to the causation of diarrhea is because aeromonads are heterogeneous and because maybe only some subgroups are pathogenic ${ }^{15}$. Despite the identification of a variety of virulence factors in Aeromonas spp., including enterotoxins, cytotoxins, hemolysins, aerolysins, proteases, hemagglutinins, and the ability to adhere to and invade tissue culture cell lines ${ }^{26}$, the linkage of these factors to the diarrheagenic ability of the isolates has not been clearly demonstrated. Besides, a high prevalence of mixed infections of Aeromonas sp. with other pathogens has been observed; it is also possible that multiple pathogens act synergistically to produce diarrhea ${ }^{1}$.

Aeromonads are currently divided into 14 DNA HGs, genomospecies, or genospecies and 14 phenospecies. The HGs are identified by a variety of methods, including DNA-DNA hybridization, PCR amplification, rDNA restriction, restriction fragment length polymorphism analysis, and pulsed-field gel electrophoresis ${ }^{9}$. However, these methods are relatively complex and not amenable to use in many laboratories. Fortunately, it has been reported that $98 \%$ of aeromonads can be accurately identified to the genospecies level by a battery of biochemical tests ${ }^{1,9}$.

Among the 14 Aeromonas species described, only five ( $A$. hydrophila, A. caviae, A. jandaei, A. schubertii and A. veronii [both biovars]) are currently recognized as human pathogens. A. hydrophila, A. caviae and A. veronii bv. sobria are regularly isolated from laboratory 


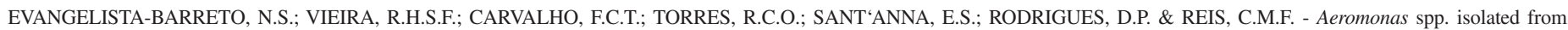
oysters (Crassostrea rhizophorea) from a natural oyster bed, Ceará, Brazil. Rev. Inst. Med. trop. S. Paulo, 48(3):129-133, 2006.

materials and related to extra-intestinal and systemic infections, including septicemia, wound infections, meningitis, peritonitis and hepatobiliary disease ${ }^{9}$.

Mesophilic, motile Aeromonas are found in freshwater, brackish water and estuaries ${ }^{25}$. They are also common contaminants of fresh foods, including fish and other seafoods ${ }^{6}$. These bacteria are plentiful in tropical regions, mainly on summer months, and have been described as the probable cause of bacterial intestinal bacterial enteritis which affects mostly children and travelers who present a moderate form of diarrhea and, sometimes, a severe form similar to cholera ${ }^{17}$.

There are a few published cases in which Aeromonas spp. have been strongly suspected as a cause of food-borne gastroenteritis. Among suspected foods, prefrozen or inadequately cooked seafood and oysters predominate $^{12}$.

Studying oyster samples, TSAI \& $\mathrm{CHEN}^{27}$ isolated A. hydrophila strains in $50 \%$ of them, indicating the high potential of infection which could come from eating raw oysters.

A. caviae and A. hydrophila of particular relevance have been frequently mentioned in the last ten years as being related to intestinal infections in men, relatively to the consumption of a variety of foods, although all species of this genus are presently known as emergent pathogens ${ }^{22}$. Such designation involves also the increase of its incidence, particularly on skin and soft tissues, especially after traumas exposed to aquatic or terrestrial environment. It is a very harsh condition to immunocompromised patients, where it is usually more severe and eventually fatal. These aspects make it difficult to recognize the infecting dose pointed out as being $10^{5}$ to $10^{8}$, even though studies in some countries have effectively determined it around $10^{8}$ cells $/ g$ in food related to foodborne diseases ${ }^{14}$.

The present study aimed to quantify and identify Aeromonas spp. from oysters (Crassostrea rhizophorea) collected from a natural oyster bed at the Cocó River estuary in the Sabiaguaba region (Fortaleza, Ceará, Brazil); as well as to verify the susceptibility of the isolated strains to stand some antimicrobial agents.

\section{MATERIAL AND METHODS}

Sample collection: From April to October/2002 thirty oyster (Crassostrea rhizophorea) collections were made fortnightly, in a natural oyster bed, at the Cocó river estuary, region of Sabiaguaba (Fortaleza, Ceará, Brazil), during low tide. The site chosen is an area of oysters (Crassostrea rhizophorea) exploitation, located $200 \mathrm{~m}$ from the river's mouth between latitudes $03^{\circ} 46^{\prime} \mathrm{S}$ and $03^{\circ} 47^{\prime} \mathrm{S}$. In each collection 35 to 40 units were examined, totalizing about 1200 units.

Samples were transported in refrigerated isothermal boxes to the microbiology laboratory at the Instituto de Ciências do Mar/LABOMAR/ $U F C$ and analyzed immediately.

Bacterial isolation: The oysters were washed under running water and opened aseptically. Twenty five grams of the intervalvar liquid and soft meat were homogenized in a sterile blender with $225 \mathrm{~mL}$ of alkaline peptone water (APW), other dilutions following until $10^{-4}$.
The strains were isolated by the direct plating (DP) and the presence/ absence methods (P/A) on Pseudomonas Aeromonas selective agar (GSP, Merck), with $20 \mu \mathrm{g} / \mathrm{mL}$ of ampicillin (GSPA) added.

For Aeromonas enumeration the DP method was used by spreading $0.1 \mathrm{~mL}$ of each dilution onto the surface of two GSPA agar plates and incubating at $28{ }^{\circ} \mathrm{C}$ for $24 \mathrm{~h}$. After $24 \mathrm{~h}$ presumptive colonies (yellow colonies of 2-3 mm, surrounded by a yellow zone) were counted.

For Aeromonas P/A test the trypticase soy broth (TSB, Difco) added with $20 \mu \mathrm{g} / \mathrm{mL}$ of ampicillin (TSBA) was used. Aliquots of $10 \mathrm{~mL}$ from the initial dilution $\left(10^{-1}\right)$ were inoculated, in duplicate, in $10 \mathrm{~mL}$ of TSBA and incubated at $28{ }^{\circ} \mathrm{C}$ for $24 \mathrm{~h}$. After incubation, portions from each tube were streaked onto the surface of two GSPA agar plates and re-incubated.

Bacterial identification: From each plate typical colonies (2 to 5) were transferred to trypticase soy agar (Difco) for biochemical identification tests according to PALUMBO et al. ${ }^{21}$. The positive control was Aeromonas ATCC 7966.

Antimicrobial susceptibility test: Susceptibility to antibiotics was tested using the agar disk diffusion method advocated by the National Committee for Clinical Laboratory Standards ${ }^{18}$. Antimicrobial disks (ceftriaxone $30 \mu \mathrm{g}$; cephalothin $30 \mu \mathrm{g}$; chloramphenicol $30 \mu \mathrm{g}$; ciprofloxacin $5 \mu \mathrm{g}$; nalidixic acid $30 \mu \mathrm{g}$; nitrofurantoin $300 \mu \mathrm{g}$; sulfamethoxazole-trimethoprim $23.75 / 1.25 \mu \mathrm{g}$ and tetracycline $30 \mu \mathrm{g}$ ) were obtained from Oxoid.

\section{RESULTS AND DISCUSSION}

From thirty collections of oysters, 20 (67\%) presented positive results for Aeromonas. Its presence in the aquatic environment where mollusks may be recognized as indicators of fecal contamination present significant correlation ${ }^{2}$; ORMEM \& OSTENOVIK ${ }^{20}$ referred to an increase in human infections risk levels through direct exposure of wounds to the contaminated environment or the consumption of food, particularly those consumed raw. Meanwhile, cross contamination and asymptomatic food handlers are also relevant sources in such products as milk and milk products, poultry, pork, vegetables and eggs 16,19 .

In general Aeromonas spp. are common contaminants of fish and seafood, since they are ubiquitous in the water environment ${ }^{6}$. It is important to point out that the stream that drains into the estuary mentioned in this study bathes several shantytowns which have no basic sewage systems, thus increasing environmental contamination.

In Table 1 results from the oysters analysis are presented with species identified and the number of strains isolated from each method.

With direct plating (DP) method $15(50 \%)$ collections were positive for Aeromonas and by P/A method 13 (43\%) collections were found. However, considering analysis from both methods, total positive results increase to $20(67 \%)$ collections. These results are similar to those found by RALL et al. ${ }^{23}$ who isolated 24 (48\%) samples of Aeromonas from commercial fish in São Paulo, Brazil with direct plating (DP) method and 21 (42\%) with P/A method. 
Using both methods HÄNNINEN et al. ${ }^{6}$ isolated Aeromonas from fish samples (93\%), fish eggs (100\%) and shrimp (16\%) in Helsinki, Finland.

In 30 collections carried out eight species were identified, most frequent ones being $A$. veronii bv. sobria and $A$. media (11 collections), followed by A. caviae (7), A. trota (3), A. sobria and Aeromonas sp. (2) and A. eucrenophila (1) (Table 1).

Even though no virulence tests were performed it is known that $A$. veronii bv. sobria (HG8) and A. caviae (HG4) are associated with human diarrhea ${ }^{6}$. According to CHOPRA \& $\mathrm{HOUSTON}^{3}$ A. caviae and $A$. veronii have been frequently isolated from human infections and their capacity to produce a variety of biologically active extra cellular products, including hemolysins, cytotoxins, enterotoxins and endotoxins have been demonstrated. GRANUM et al. ${ }^{5}$ analyzed nine A. caviae strains from food and water in Norway and observed cytotoxins production in four of them. ALBERT et al. ${ }^{1}$ analyzed 115 samples from children with diarrhea and isolated $A$. caviae and $A$. veronii bv. sobria in $33.9 \%$ and $18.3 \%$ of them respectively.
Bacteremia from Aeromonas has been more frequent in male adults with classic signs of septicemia (fever in $90 \%$ or more patients and shivers in $70 \%$ of them) A. hydrophila and A. veronii (both biovars) being responsible for more than $90 \%$ of the reported episodes ${ }^{10}$. Although it has not been implicated in any kind of infection, Aeromonas media is frequently isolated from fecal samples ${ }^{9}$.

A. trota has been mentioned in the literature as the responsible for a diharrea episode in a 3 -year old child ${ }^{24}$, while GRANUM et al. ${ }^{5}$ found cytotoxin production in three strains of this same species isolated from crab, water and powdered eggs.

Aeromonas sobria and A. caviae may cause enteritis in anyone or septicemia in immunocompromised persons ${ }^{4}$. The first one is commonly isolated from recreational lakes and rivers, while A. caviae prevails in marine water and is also found in sewage contaminated water ${ }^{25}$.

Sabiguaba's mangrove is known to bear contamination both from the river that bathes it as from the presence of countless beach shacks near its margins with meager hygiene conditions.

Table 1

Aeromonas species isolated from mangrove oysters (Crassostrea rhizophorea), by presence/absence (P/A) and direct plating (CFU/g) methods

\begin{tabular}{|c|c|c|c|c|}
\hline Collect & $\mathrm{P} / \mathrm{A}$ & *Species (No. of strains) & $\mathrm{CFU} / \mathrm{g}$ & *Species (No. of strains) \\
\hline $1^{\circ}$ & A & - & $<10^{2}$ & - \\
\hline $2^{\circ}$ & A & - & $1.2 \times 10^{3}$ & Avs (1) \\
\hline $3^{\circ}$ & A & - & $<10^{2}$ & - \\
\hline $4^{\circ}$ & A & - & $3.1 \times 10^{4}$ & Avs (1) \\
\hline $5^{\circ}$ & A & - & $<10^{2}$ & - \\
\hline $6^{\circ}$ & $\mathrm{P}$ & Ac (1), Am (1), Avv (1) & $1.2 \times 10^{3}$ & Ac (1) \\
\hline $7^{\circ}$ & A & - & $4.0 \times 10^{4}$ & Am (1) \\
\hline $8^{\circ}$ & $\mathrm{A}$ & - & $1.5 \times 10^{3}$ & Avs (1) \\
\hline $9^{\circ}$ & $\mathrm{P}$ & Am (1), At (3) & $<10^{2}$ & - \\
\hline $10^{\circ}$ & $\mathrm{P}$ & $\operatorname{Am}(1), \operatorname{Avv}(1)$ & $1.4 \times 10^{4}$ & Am (1) \\
\hline $11^{\circ}$ & A & - & $<10^{2}$ & - \\
\hline $12^{\circ}$ & $\mathrm{P}$ & Ac (1), Am (1), Avs (1) & $2.8 \times 10^{3}$ & Ac (1) \\
\hline $13^{\circ}$ & $\mathrm{P}$ & Am (2) & $6.9 \times 10^{3}$ & $\operatorname{Ac}(2), \operatorname{Am}(1), \operatorname{Avs}(1)$ \\
\hline $14^{\circ}$ & $\mathrm{A}$ & - & $9.0 \times 10^{3}$ & Ac $(2)$ \\
\hline $15^{\circ}$ & $\mathrm{P}$ & At (1) & $9.0 \times 10^{2}$ & Ac (1) \\
\hline $16^{\circ}$ & A & - & $7.3 \times 10^{3}$ & Asp (2), Avs (1) \\
\hline $17^{\circ}$ & $\mathrm{P}$ & Asp (1), At (1), Avs (4) & $1.4 \times 10^{4}$ & Asp (2), As (1), Avs (1) \\
\hline $18^{\circ}$ & $\mathrm{P}$ & Am (1) & $2.0 \times 10^{3}$ & Ac (1), Ae (1), Am (2), As (1), Avs (1) \\
\hline $19^{\circ}$ & $\mathrm{A}$ & - & $<10^{2}$ & - \\
\hline $20^{\circ}$ & $\mathrm{P}$ & Ac (1), Am (2) & $<10^{2}$ & - \\
\hline $21^{\circ}$ & A & - & $<10^{2}$ & - \\
\hline $22^{\circ}$ & A & - & $<10^{2}$ & - \\
\hline $23^{\circ}$ & $\mathrm{P}$ & Am (1) & $<10^{2}$ & - \\
\hline $24^{\circ}$ & $\mathrm{A}$ & - & $<10^{2}$ & - \\
\hline $25^{\circ}$ & $\mathrm{P}$ & Am (1) & $<10^{2}$ & - \\
\hline $26^{\circ}$ & $\mathrm{A}$ & - & $9.4 \times 10^{3}$ & Avs (1) \\
\hline $27^{\circ}$ & A & - & $<10^{2}$ & - \\
\hline $28^{\circ}$ & A & - & $<10^{2}$ & - \\
\hline $29^{\circ}$ & $\mathrm{P}$ & Am (1) & $1.5 \times 10^{3}$ & Avs (1) \\
\hline $30^{\circ}$ & $\mathrm{P}$ & Avs (2) & $<10^{2}$ & - \\
\hline
\end{tabular}

*Ac (Aeromonas caviae), Ae (A. eucrenophila), Am (A. media), As (A. sobria), Asp (Aeromonas sp.), At (A. trota), Avs (A. veronii bv. sobria) and Avv (A. veronii bv. veronii) 


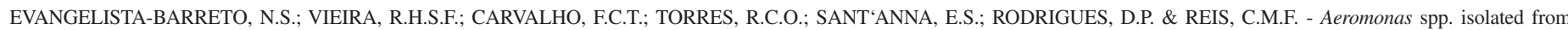
oysters (Crassostrea rhizophorea) from a natural oyster bed, Ceará, Brazil. Rev. Inst. Med. trop. S. Paulo, 48(3):129-133, 2006.

Table 2

Antibiotics susceptibility of Aeromonas strains isolated from mangrove oysters (Crassostrea rhizophorea)

\begin{tabular}{|c|c|c|c|c|c|c|c|c|}
\hline Antibiotics* & $\mathrm{TE}$ & $\mathrm{F}$ & $\mathrm{KF}$ & $\begin{array}{l}(\%) \text { sus } \\
\text { CIP }\end{array}$ & $\begin{array}{l}\text { ible to } \\
\text { CRO }\end{array}$ & SXT & $\mathrm{C}$ & NA \\
\hline Aeromonas sp. $(\mathrm{n}=5)$ & $2(40)$ & $4(80)$ & $4(80)$ & $5(100)$ & $4(80)$ & $1(20)$ & $5(100)$ & $5(100)$ \\
\hline A. caviae $(\mathrm{n}=11)$ & $9(82)$ & 11(100) & $10(91)$ & $11(100)$ & $9(82)$ & $6(55)$ & $11(100)$ & $11(100)$ \\
\hline A. media $(\mathrm{n}=17)$ & $15(88)$ & $17(100)$ & $16(94)$ & $17(100)$ & $17(100)$ & $14(82)$ & $17(100)$ & $17(100)$ \\
\hline A. sobria $(n=2)$ & $2(100)$ & $2(100)$ & $2(100)$ & $2(100)$ & $2(100)$ & $0(0)$ & $2(100)$ & $2(100)$ \\
\hline A. veronii bv. sobria $(\mathrm{n}=16)$ & $16(100)$ & $16(100)$ & $14(88)$ & $16(100)$ & $16(100)$ & $5(31)$ & $16(100)$ & $14(88)$ \\
\hline A. veronii bv. veronii $(\mathrm{n}=2)$ & $2(100)$ & $2(100)$ & $2(100)$ & $2(100)$ & $2(100)$ & $1(50)$ & $2(100)$ & $2(100)$ \\
\hline A. $\operatorname{trota}(\mathrm{n}=5)$ & $5(100)$ & $5(100)$ & $5(100)$ & $5(100)$ & $5(100)$ & $4(80)$ & $5(100)$ & $5(100)$ \\
\hline A. eucrenophila $(\mathrm{n}=1)$ & $1(100)$ & $1(100)$ & $1(100)$ & $1(100)$ & $0(0)$ & $1(100)$ & $1(100)$ & $1(100)$ \\
\hline Total $(n=59)$ & $52(88)$ & $58(98)$ & $54(92)$ & $59(100)$ & $55(93)$ & $32(54)$ & $59(100)$ & $57(97)$ \\
\hline
\end{tabular}

*Tetracycline (TE), nitrofurantoin (F), cephalothin (KF), ciprofloxacin (CIP), ceftriaxone (CRO), sulfamethoxazole-trimethoprim (STX), chloramphenicol (C) and nalidixic acid (NA). $\mathrm{n}=$ number of strains tested

In Table 2 results of the susceptibility tests of Aeromonas to eight antimicrobial agents are shown.

From the 59 strains tested, $28(48 \%)$ showed resistance to at least one of the antimicrobial agents. Increasing resistance of microbes to medication has been heightening worries of sanitary authorities.

According to literature most Aeromonas species are susceptible to tetracyclines, trimethoprim-sulfamethoxazole, third-generation cephalosporins and the quinolones ${ }^{9}$, even though a 1996 study from Taiwan found increasing resistance ${ }^{13}$.

All Aeromonas strains were sensitive to ciprofloxacin and chloramphenicol. The majority of them were sensitive to nalidixic acid $(97 \%)$, nitrofurantoin $(98 \%)$, ceftriaxone (93\%) and cephalothin (92\%).

The susceptibility profile facing tetracycline varied. All A. sobria, A. veronii (both biovars), A. trota and A. eucrenophila strains were sensitive, while A. media, A. caviae and Aeromonas sp. showed $88 \%$, $82 \%$ and $40 \%$ susceptibility, respectively. Similar susceptibility results were found by RALL et al. ${ }^{23}$ for A. sobria (100\%) and A. caviae (93\%), but different results were found for Aeromonas sp. (93\%). Meanwhile $\mathrm{KO}$ et al. ${ }^{13}$ found $59 \%$ suceptible strains to tetracycline for A. caviae and $42 \%$ for $A$. sobria. HEDGES et al. ${ }^{7}$ suggested that low resistance could be due to a plasmid.

Strains were resistant to Sulfamethoxazole-trimethoprim (46\%).

The results obtained in this study show the food examined may represent an increase in human infections risk levels, mainly due to the habit of raw oyster consumption. Although no A. hydrophila, has been isolated, the presence of A. caviae and A. veronii (both biovars) should be pointed out, as these species have been involved in several gastroenteritis cases ${ }^{6,23}$. Available data indicate that further epidemiological studies together with new taxonomic data on genospecies and on aeromonad pathogenicity are needed to elucidate the public health significance of these pathogens in food and drinking water.

\section{RESUMO}

\section{Aeromonas spp. isoladas de ostras (Crassostrea rhizophorea) coletadas em um criadouro natural, Ceará, Brazil}

Foram realizadas 30 coletas quinzenais, entre abril e outubro de 2002, de ostras (Crassostrea rhizophorea) de um criadouro natural, no estuário do rio Cocó (Fortaleza/Ceará/Brasil), objetivando-se isolar cepas de Aeromonas spp. As amostras de ostras foram submetidas aos métodos de plaqueamento direto (PD) e presença/ausência (P/A). Foram identificadas Aeromonas em $15(50 \%)$ amostras analisadas pelo método PD e em 13 (43\%) pelo método P/A. Foram isoladas: A. caviae, A. eucrenophila, A. media, A. sobria, A. trota, A. veronii bv. sobria, A. veronii bv. veronii e Aeromonas sp. A espécie predominate foi A. veronii (ambos biovars), identificada em 13 (43\%) amostras, seguida de $A$. media em 11 (37\%) e A. caviae em 7 (23\%). Das 59 cepas identificadas, $28(48 \%)$ apresentaram resistência a pelo menos um, dos oitos antibióticos testados.

\section{ACKNOWLEDGEMENTS}

The authors are grateful to the financial support of the "Fundação Cearense de Apoio ao Desenvolvimento Científico e Tecnológico" (FUNCAP) and to the "Instituto de Ciências do Mar" where this research was performed.

\section{REFERENCES}

1. ALBERT, M.J.; ANSARUZZAMAN, M.; TALUKDER, K.A. et al. - Prevalence of enterotoxin genes in Aeromonas spp. isolated from children with diarrhea, healthy controls, and the environment. J. clin. Microbiol., 38: 3785-3790, 2000.

2. ARAÚJO, R.M.; ARRIBAS, R.M. \& PARES, R. - Distribution of Aeromonas species in water with different levels of production. J. appl. Bact., 71: 182-186, 1991.

3. CHOPRA, A.K. \& HOUSTON, C.W. - Enterotoxins in Aeromonas-associated gastroenteritis. Microbes Infect., 1: 1129-1137, 1999.

4. FDA/U.S.A. Food and Drug Administration/CFSAN - Aeromonas hydrophila. URL: <http://www.cfsan.fda.gov/ mow/chap17.html>. Accessed in: March 19, 2004. 


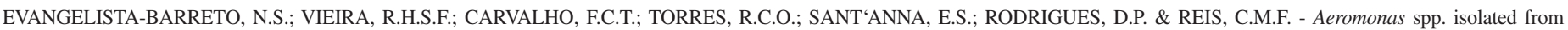
oysters (Crassostrea rhizophorea) from a natural oyster bed, Ceará, Brazil. Rev. Inst. Med. trop. S. Paulo, 48(3):129-133, 2006.

5. GRANUM, P.E.; O'SULLIVAN, K.; TOMÁS, J.M. \& ORMEN, O. - Possible virulence factors of Aeromonas spp. from food and water. FEMS Immunol. med. Microbiol. 21: $131-137,1998$

6. HÄNNINEN, M.L.; OIVANEN, P. \& HIRVELÄ-KOSKI, V. - Aeromonas species in fish, fish-eggs, shrimp and freshwater. Int. J. Food Microbiol., 34: 17-26, 1997.

7. HEDGES, R.W.; SMITH, O. \& BRAZIL, G. - Resistence plasmids of aeromonads. J. gen. Microbiol., 131: 2091-2095, 1985.

8. HUSS, H.H. - Control of indigenous pathogenic bacteria in seafood. Food Control, 8 : 91-98, 1997.

9. JANDA, J.M. \& ABBOTT, S.L. - Evolving concepts regarding the genus Aeromonas: an expanding panorama of species, disease presentations, and unanswered questions. Clin. infect. Dis., 27: 332-344, 1998.

10. JANDA, J.M. \& ABBOTT, S.L. - Human pathogens. In: AUSTIN, B.; ALTWEGG, M.; GOSLING, P.J. \& JOSEPH, S.S. The genus Aeromonas. Chichester, J. Wiley \& Sons, 1996. p. 151-173.

11. JOSEPH, S.W. \& CARNAHAN, A.M. - Update on the genus Aeromonas. ASM news, 66: $218-223,2000$

12. KIROV, S.W. - The public health significance of Aeromonas spp. in foods. Int. J. Food Microbiol., 20: 179-198, 1993.

13. KO, W.C.; YU, K.W.; LIU, C.Y. et al.- Increasing antibiotic resistance in clinical isolates of Aeromonas strains in Taiwan. Antimicrob. Agents Chemother., 40: 1260-1262, 1996.

14. KROVACEK, K. \& AHMED, F. - Aeromonas species. In: MILIOTIS, M.D. \& BIER, J.W. - International handbook of foodborne pathogens. New York, Marcel Dekker, 2003.

15. KUHN, I.; ALBERT, M.J.; ANSARUZZAMAN, M. et al. - Characterization of Aeromonas spp. isolated from humans with diarrhea, from healthy controls and from surface water in Bangladesh. J. clin. Microbiol., 35: 369-373, 1997.

16. KUMAR, A.; BACHHIL, V.N.; BHILEGAONAKAR, K.N. \& AGARWAL, R.K. Occurrence of enterotoxigenic Aeromonas species in foods. J. commun. Dis., 32: 169-174, 2000.

17. MONTEIL, H. \& HARF-MONTEIL, C. - Aeromonas infections. Presse méd., 26: 1790$1798,1997$.
18. NCCLS/National Committee for Clinical Laboratory Standards - Performance standards of antimicrobial susceptibility testing. M100-S13, v. 22, No. 1. Villanova, 2003.

19. NEYTS, K.; HUYS, G.; UYTTENDAELE, M.; SWINGS, J. \& DEBEVERE, J. - Incidence and identification of mesophilic Aeromonas sp. from retail foods. Lett. appl. Microbiol., 31: 359-363, 2000.

20. ORMEN, O. \& OSTENSVIK, O. - The occurrence of aerolysin-positive Aeromonas spp. and their cytotoxicity in Norwegian water sources. J. appl. Microbiol., 90: 797-802, 2001.

21. PAlumbo, S.; ABEYTA, C.; STELMA, G. et al. - Aeromonas, Acrobacter and Plesiomonas. In: DOWNES, F.P. \& ITO, K. Compendium of methods for the microbiological examination of foods. 4. ed. Washington, APHA, 2001. p. 283290 .

22. PEREIRA, C.S.; VIANA, C.M.; POSSAS, C.A. et al. - Aeromonas spp. e Plesiomonas shigelloides isoladas a partir de mexilhões in natura e pré-cozidos no Rio de Janeiro/ RJ. Cienc. Tecnol. Aliment., 24: 562-566, 2004.

23. RALL, V.L.M.; IARIA, S.T.; HEIDTMANN, S. et al. - Aeromonas species isolated from pintado fish (Pseudoplatystoma sp.): virulence factors and drug susceptibility. Rev. Microbiol. (S. Paulo), 29: 222-227, 1998.

24. REINA, J. \& LOPEZ, A. - Gastroenteritis caused by Aeromonas trota in child. J. clin. Path., 49: 173-175, 1996.

25. RODRIGUES, D.P. \& RIBEIRO, R.V. - Aeromonas. In: VIEIRA, R.H.S.F. Microbiologia, higiene e qualidade do pescado: teoria e prática. São Paulo, Varela, 2004. p. 151174.

26. THORNLEY, J.P.; SHAW, J.G.; GRYLLOS, I.A. \& ELEY, A. - Virulence properties of clinically significant Aeromonas species: evidence for pathogenicity. Rev. med. Microbiol., 8: 61-72, 1997.

27. TSAI, G.J. \& CHEN, T.N. - Incidence and toxigenicity of Aeromonas hydrophila in seafood. Int. J. Food Microbiol., 31: 121-131, 1996.

Received: 10 November 2004

Accepted: 30 November 2005 